\title{
Investments in Contemporary \\ Russian Artwork as an Alternative Form of Investment
}

\author{
Alexandra Galanova \\ Ph.D. in Economics, assistant professor \\ ORCID \\ E-mail: agalanova@hse.ru
}

National Research University Higher School of Economics, Moscow, Russia

\section{Mariia Lutsenko}

research assistant

ORCID

E-mail: marialutsenko1@gmail.com

National Research University Higher School of Economics, Moscow, Russia

\section{Jorge Zamorano}

Ph.D. in Economic Sciences, assistant professor

$\underline{\text { ORCID }}$

E-mail: jorge.zamorano.f@usach.cl

Department of Industrial Engineering, University of Santiago, Santiago, Chile

Journal of Corporate Finance Research, Vol. 14, No. 3, pp. 7-18 (2020)

DOI: https://doi.org/10.17323/j.jcfr.2073-0438.14.3.2020.7-18

Received 13 April 2020 | Peer-reviewed 15 May 2020 | Accepted 25 May 2020 


\section{Investments in Contemporary Russian Artwork as an Alternative Form of Investment}

\section{Abstract}

The purpose of this work is to evaluate the efficiency of investments in the artworks of contemporary Russian painters and to compare the effectiveness of these investments with the effectiveness of investments in stock, bond and real estate markets in Russia and the USA.

For this research, we first conduct a hedonic regression analysis on the data available for the time period 1950-

2019. After that, we build a hedonic price index for the canvases of contemporary Russian artists. A selection of 613 transactions was made, involving canvases from 57 contemporary Russian painters.

According to the results of our study, the trend of this index largely reiterates the price behaviour for world contemporary art market. However, the results of this study indicate that investments in contemporary Russian art do not outperform investments in instruments of Russian and American capital and real estate markets. These results were derived by applying the CAPM model, which demonstrated that Russian art as a form of alternative investment is not advisable for the purposes of diversification of investment portfolios. Based on these findings, contemporary Russian art in general can be considered an unattractive instrument for Russian and foreign investors.

The scientific novelty of this paper resides in a comparison among those on similar topics. Unlike our study, few of the academic papers published over the last several decades have presented any quantitative analysis with regard to art's investment performance, and an even smaller amount of research has been devoted to the analysis of Russian art markets.

Key words: works of contemporary Russian painters, alternative investments, profitability, portfolio diversification, securities, real estate

JEL classification: G39, G11, G12, Z11 


\section{Introduction}

The history of the art market dates back many centuries. Artwork has been sold in auctions, bought from art-dealers in private galleries, and ordered directly from artists. However, the idea of art as a form of alternative investment only became popular after the Second World War, and became especially favoured after series of crises on financial markets in the second part of the twentieth century [1]. The increasing interest in the role of works of art as investment assets can be attributed to two main causes.

The first cause was the general trend towards expansion of potential areas of investment. During the postwar period, investors actively sought out alternative investment possibilities that pushed beyond the already-existing classes of investment assets. Traditionally, such target areas belonged primarily to those classes of securities and real estate which produced consistent profit and displayed stability. Artwork would prove to be a relatively new class of assets, of quite a significant scale. A growth in the degree of wealth of modern fund holders resulted in a substantial increase in the prices of works of art, and this steady increase in their prices transformed these previously non-monetary objects into a particular type of capital. This dynamic prompted concomitant growth in the private fortunes of the owners.

The second cause was the trend towards development of defenses against market risks. On the financial markets, there is a tendency towards price growth volatility for financial assets. The reason for this volatility stems from the non-material economic nature of certain assets, or from the absence of such anchoring factors as material costs, dependence on "material" technologies, and man-hours. The growth of volatility makes it necessary to search for assets with a substantially low correlation with more traditional financial instruments. Such assets have a crucial significance for contemporary portfolio building, as evinced by almost every existing collective investment scheme. The material nature of art assets, (as opposed to the intangibility of securities investments), and the relative rarity of valuable artworks when compared with real estate assets, promoted the eventual use of art as an instrument for risk diversification. The novelty of valuable artwork may also promote the value of an investment portfolio by a significant degree in case of price drops in the financial markets during periods of economic recession.

For these reasons, the market for works of art gained recognition in the financial world in the late decades of the twentieth century as an independent economic category, with its own means of organisation, means of doing business, and pricing models.

Taking into account the fact that different art movements have their own determinants of offers and demands, it is possible to assume that this tendency also applies to art markets in individual countries. The Russian market for art objects significantly differs from the more widely-examined American and European markets. On the one hand, Russian capital holders considerably accede to the elite of the developed countries as far as their degree of total wealth is concerned. On the other hand, the revenue levels of the majority of the Russian population does not permit this majority to allocate a considerable amount of money for the acquisition of valuable art objects.

There is a limited amount of scientific research containing detailed econometric analyses of the Russian art market, including calculations of profitability attained as a result of investment in the works of contemporary Russian painters only. Only some researchers have utilised the available empirical data, and the majority of the transactions analysed in these data are deals involving wellknown canvases with a known history of resale.

\section{Methods of evaluation of profitability for investments in works of art, and research into the Russian art market}

Analytical methods for measuring the profitability of investment in artwork were thoroughly examined in the article by B. S. Frey, R. Eichenberger [2]. There are two primary methods of evaluation: repeated sales regression (RSR) and hedonic regression. Most of the indices available at the moment are derived from the results of these regressions.

The repeated sales method has been widely used by researchers, including in one of the first analyses of the art market, by W. J. Baumol [3]. This method was also applied in the work of S. L. Glekov [4], where it was concluded that maximum profitability could be obtained with the works of contemporary painters, and the use of artworks for risk diversification could increase the effectiveness of investment portfolios. However, according to B. S. Frey, R. Eichenberger [2] not all art objects have a particularly long history of sales and resales, and obtaining reliable results through this method can be difficult. Additionally, the use of the method of repeated sales cannot be used for the analysis of profitability for those objects of contemporary art that were not present yet on the aftermarket, or for which the number of deals was relatively small (O. Chanel, L. Gerard-Varet, V. Ginsburgh, [5]).

The second method, becoming more popular among those analysing the art market, is the method of hedonic regression. This regression takes into account the particular characteristics of each art object, and thus leads to more reliable evaluations. This method was first suggested by L. Court [6]. A detailed analysis of the model of hedonic regression and the application of its features to the art market was presented in the work of O. Chanel, L. Gerard-Varet, V. Ginsburgh, [5]. G. Gandela, A. Scoru [7] noted that the method of hedonic regression is preferable to the method of repeated sales, as the prices for paintings could be explained by distinct factors, which vary for every individual art object, and, further, that for 
the evaluation of artwork its repeated sales price is not necessary. The method of hedonic regression is usually used when evaluating local markets (J. Nahm [8] - South Korea, H. Higgs and J. Fordter [9] - Australia, G. Candela and A. Scoru [7] - Italy). It was the use of the method of hedonic regression that helped H. Higgs and J. Fordter [9] and J. Nahm [8] to identify the influence of the size of the canvas on the price of the art object in countries where they applied the survey - a phenomenon that has no significant influence in other countries.

Transaction costs play a huge part in the functioning of the art market [7]. Insurance, security and transportation costs are examples of costs in this category. Unfortunately, the magnitude of these costs can vary greatly within one auction house. Even more importantly, there is no public information on the amount of transaction costs for a particular piece of art. Thus, it is almost impossible to take into account the value of such costs when constructing the indexes of art markets. Besides transaction costs, there are also indirect costs associated with investing in art markets. These costs can include lack of liquidity in the art market, risks associated with the authenticity of the art object, the inability to take the art object out of the country, and the possibility of theft of the art object [4].

Nevertheless, transaction costs associated with art markets may significantly reduce returns on art investments [10]. Therefore, in this study we attempt to quantify these transaction costs based on publicly available estimates incorporated in existing academic literature. As shown by G. Urbi, V. Gwendoline and E. Villalobos [11], transaction costs in art markets are one of the highest among all asset classes. According to R. J. Campbell [10], these costs can amount to $30 \%$ of sale price. Similar estimates were provided by B. S. Frey, R. Eichenberger [2], who found that auction fees may range between $10 \%$ and $30 \%$. Alternatively, O. Ashenfelter and K. Graddy [12] found that transaction costs may range from $20 \%$ to $28 \%$. As no research is available with respect to transaction costs on Russian art markets, in accordance with previously established scientific evidence we assume that on average, seller's commission, insurance, storage, and other types of costs amount to $30 \%$ of the sale price in this study. A higher point estimate is also justified by a low level of transparency in the Russian art markets as a lack of information availability leads to severe market inefficiencies and, subsequently, higher transaction costs [13].

Currently, there are only a few surveys focusing on an analysis of the Russian art market, and fewer still that apply an empirical analysis of the data from Russian auctions, or of the results of the sales of artwork from Russian painters outside the domestic market. A. N. Sukharev [14] uses data from Russian auctions to define the operative art market dynamics. In particular, the author specifically denotes the index 'ARTIMX-RUS', which represents the price index of Russian art. This index is calculated separately for paintings and graphic arts and for the art from the most popular painters. According to the results of A. N. Sukharev's analysis, he concludes that from 2001 to 2013 the real value of artwork significantly increased (23\% for world art and $123 \%$ for Russian art). One of the most interesting conclusions of this article is that in 2013 the price index for Russian art was 2 times bigger than the price index for art in general. On foot of this fact, A. $\mathrm{N}$. Sukharev draws the conclusion that Russian art is an attractive instrument for investments. The price index of contemporary art used by the author takes into account the prices of art from all (not only Russian) contemporary painters. He indicates that the price index for the canvases of impressionists and modernists is behind the general trend of the art prices, but this relationship is not thoroughly explained.

A comparison of art objects, including Russian ones, with traditional financial assets is made in the work of A. V. Mikhlin [15]. As A. N. Sukharev [14], A. V. Mikhlin analyses in detail different indexes of the ARTIMX group and compares the movement of the ARTIMX index with the index of the Moscow bourse from 2001 to 2012. A. V. Mikhlin came to the conclusion that the crisis in the Russian art market began after the fall of the Russian stock market in 2009, with a time lag of 6-12 months. Additionally, his work illustrated the connection between the art market index and the price changes of precious metals. In general, the art market has a weak correlation with the market for precious metals. The strongest correlation was found between the art market and the gold market. The main conclusion of A. $\mathrm{V}$. Mikhlin is that art objects can be included in financial portfolios to increase diversification. Nevertheless, the profitability potential of art is still lower than the profitability of traditional financial instruments. When comparing the index of the art market with the index of the Moscow bourse, the author used the common price index for art objects. However, in line with conclusions drawn from the works of foreign researchers, local peculiarities in the art market could significantly influence the level of profitability. Additionally, as was noted in the work of A. N. Sukharev [14] the price index of artworks from Russian painters was a little bit higher than the general price index for art.

Schurina S. V. [16] presented not only a comparative study of the main Russian auction houses, but also a detailed description of the actual situation in the Russian art market. First, she outlined that the Russian market is not as developed in comparison to countries such as the US, the UK and France, but is relatively stable. She also found an increase of interest in investment in art around 2014, mainly connected with the changes in the Russian economic environment during that period. Additionally, the author focuses on the increasing interest of Russian banks in establishing their own collections. Schurina S. V. supposes that in doing so, the banks provide an example to private investors, thus demonstrating that art can be also considered as a legitimate and reasonable object for investments. 


\section{Fundamentals of the Russian art market}

'ARTinvestment.RU' is a database which contains information on more than 190000 deals with the artwork of about 10000 painters in Russia [17]. According to the most recent information from this resource, the Russian art market shrunk by $25 \%$ in 2018 , whilst the global art market grew 10\% [18]. As V. Bordanov, - one of the leading authors of the portal - has said, this decrease in demand for the art objects of Russian painters can be explained by Russia's domestic economic situation. V. Bogdanov also noted high transaction expenses for Russian art objects. According to his opinion, many foreign buyers refuse to buy objects of Russian art because of the enormous amount of formal documentation processes involved, although the export of Russian art objects is permitted by the government.

These suppositions are confirmed by the annual report of Artprice.com [19] - an international resource in the domain of evaluation of art market. According to the data of this report, all the most important art market proxies grew in 2018 - the first time since 2008. For the period mentioned, every proxy grew by approximately $18 \%$, and the world auction turnover grew by $19 \%$ to 1.9 billion USD. The volume of transactions also grew by $17 \%$, and the number of lots sold was about 67000 . The market index of contemporary art increased by $18.5 \%$. The sole indicator that showed no change for the period studied was the percentage of non-sold art objects, which was 39\%. In general, the data of the report illustrates a steady and accelerated growth of sales in contemporary art auctions. Notwithstanding the above-mentioned decline in the Russian art market in 2018, there were several important deals involving the canvases of contemporary Russian painters. The most expensive canvases were sold in auctions abroad [20]. Of the ten most expensive canvases, more than half (6 paintings) were sold in the auction 'Vladey'. The price of the most expensive painting ("Portrait of group with watermelon", 1963, by Oleg Tselkov) was 170688 Euro without commission. As for the volume of the market itself, the Russian analytical agency 'InArt', which deals with contemporary art, suggested that in 2018 the volume of the Russian contemporary art market was about $22.4 \mathrm{mln}$ Euro.

Consequently, the share of the Russian contemporary art market in terms of the world art market was only $1.35 \%$ in 2018. Nevertheless, from 2017 to 2018 that market share grew by $20.45 \%$ (or $0.8 \mathrm{mln}$ Euro) [21]. If this trend were to continue, it would be possible to hope for the further growth in the share of sales for Russian painters in the world market.

Some data about the Russian art market was mentioned in the analytical report "Art Market 2018" issued from Swiss bank UBS and Art Basel [22]. According to this report, there are only 2 Russian collectors in the "Top 200 Collectors". Most of the largest collectors reside in the US. Taking into account that the global share of dollar multimillionaires in Russia in 2017 was 3\% (more than in all European countries excluding Gemany at 4\%), but in Europe there are more art collectors from the list "Top 200 Collectors", it is possible to surmise that Russian investors prefer not to invest their money in art objects, at least in large amounts.

Figure 1. Sales volume of Russian art objects in billions USD

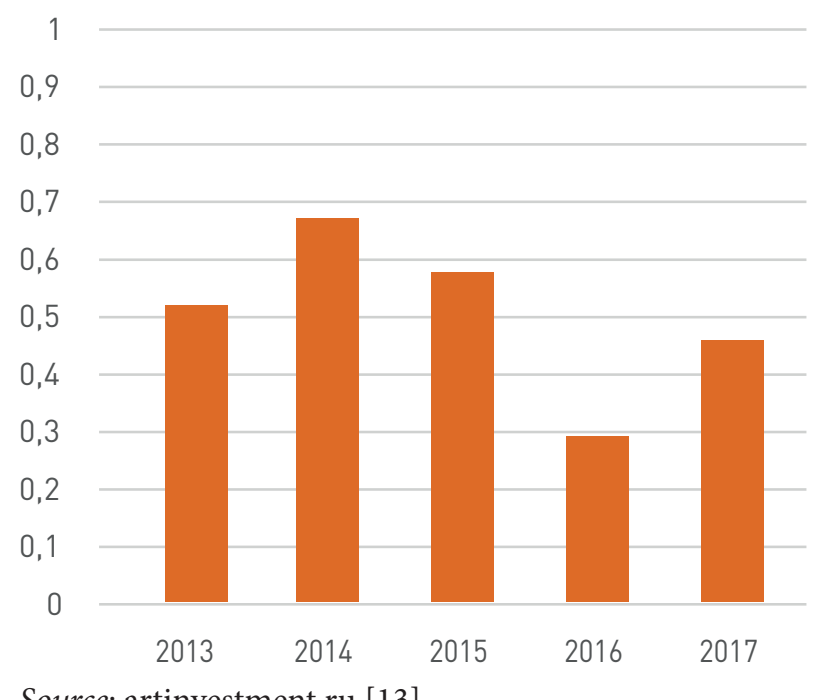

Source: artinvestment.ru [13].

Figure 2. Sales volume of art objects on world markets in billions USD

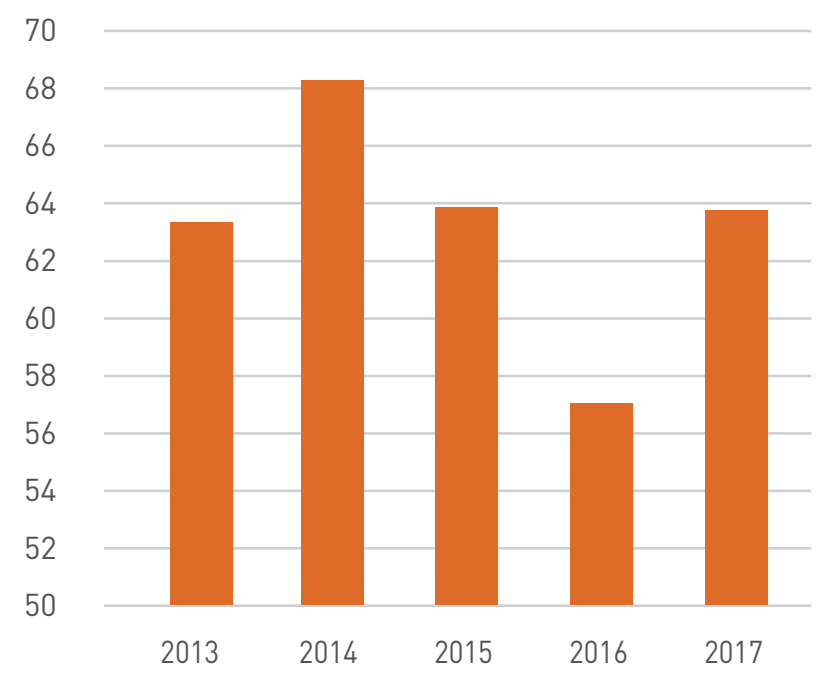

Source: Art Market Report [18].

The share of contemporary art in the total volume of artwork sales considerably differs between the Russian and the global markets. For example, in Russia the share of the contemporary art market is $4.95 \%$ of the total volume, while this percentage is $12 \%$ for the global market [18]. We may assume that Russian contemporary art is a less popular type of investment than the paintings of old masters, which have traditionally been of more interest in Russian and foreign auctions.

The data for total volume of sales in Russian and foreign art markets for 2013-2017 is presented in Figures 1 and 2. We can see from these figures that changing trends in the volume of sales of art objects on global markets are similar to 
the changes in sales volume for Russian art objects. There were no significant deviations in the period examined, and so therefore, it is possible to assume that in general there are no important differences between the volume changes in global and Russian markets. Hence, this analytical perspective should not be included among those variables connected with the particularities of Russian art market.

\section{Formation and analysis of price indexes for Russian contemporary art}

For the purposes of this research, a manual selection of 613 transactions was made, involving canvases from 57 contemporary Russian painters. This selection was made on the basis of the rating of the professional consulting agency 'InART' [23]. The main descriptive statistics of the selection variables is shown in Table 1.

As Table 1 shows, the earliest year of canvas creation in the selection was 1952, and the latest was 2018 . However, the time lapse between the earliest and the latest year of canvas sale in the selection is considerably smaller, as the first sale was in 2006 and the last one it 2019. In the selection there are also artworks which were created and sold during the same year. The maximum time lapse between the creation and sale of the canvas in this selection was 66 years. The average time lapse between the creation and sale of the canvas was 15 years. The mean surface of the canvas is $9448 \mathrm{~cm}^{2}$, the lowest figure is $60.84 \mathrm{~cm}^{2}$, and the highest is $109200 \mathrm{~cm}^{2}$. The mean value of canvases sold was 14602 USD. The canvas with the lowest price was sold for 46 USD ("Construction of hydraulic power station on Irtysh" by Arkady Petrov), and the highest sale price was 96583 USD ("Infinite beach" by Natalya Nesterova).

The creation of a new index is motivated by the following reasons. Most existing art indices base their calculations on top-100 paintings for a given period of time. Therefore, their sample is biased towards more expensive art objects and, in part, more popular artists. In our research, we take the perspective of a small/medium individual investor who can freely choose between paintings with the price range presented in Table 1. Besides this, in many indices contemporary and modern art are united into one category. This is partially motivated by the fact that there are not that many potential buyers for each category separately.

Table 1. Main descriptive statistics of continuous variables of selection

\begin{tabular}{|c|c|c|c|c|c|}
\hline Variable & (1) $\mathbf{N}$ & (2) Mean value & (3) Standard deviation & (4) Min & (5) Max \\
\hline Year of creation & 613 & 1998 & 14.30 & 1952 & 2018 \\
\hline Year of sale & 613 & 2013 & 3.752 & 2006 & 2019 \\
\hline Width of the canvas $(\mathrm{cm})$ & 613 & 80.75 & 51.56 & 7.800 & 287.5 \\
\hline Height of the canvas $(\mathrm{cm})$ & 613 & 86.59 & 59.69 & 6 & 448.5 \\
\hline Area of canvas $\left(\mathrm{cm}^{2}\right)$ & 613 & 9448 & 11635 & 60.84 & 109200 \\
\hline Sale price (USD) & 613 & 14602 & 18784 & 46 & 96583 \\
\hline Adjusted sale price (USD) & 613 & 10221 & 13149 & 32 & 67608 \\
\hline $\begin{array}{l}\text { Number of years since the } \\
\text { year of creation }\end{array}$ & 613 & 15.37 & 13.70 & 0 & 66 \\
\hline
\end{tabular}

In our calculations, we take these factors into account and deliberately seek to overcome these issues.

The hedonic regression method was applied to gauge the price index of contemporary Russian art. As previously mentioned, the unfavorability of the use of the repeated sales regression method is explained by the particularities of the existing data. The methods applied to the analysis of investment projects with unconventional cash flows were also not applicable, due to non-recurring nature of cash flows related to art investments [24]. Only 3.92\% of the artworks in the selection were sold on auctions more than once. The basic functional form of index is calculated as follows:

$$
\ln P_{i t}=\sum_{k=1}^{n} a_{k} x_{k i}+\sum_{\tau=0}^{t} \sum_{j=1}^{m} \theta_{j t} w_{i j t}+c(t)+\varepsilon_{i t}
$$

The natural logarithm of the sale price of the art object "I" at the time " $\mathrm{t}$ " is used as the dependent variable. The variable " $\mathrm{x}$ " includes the timely constant characteristic of the object, the variable " $w$ " is the characteristic over time. In this study, these variables can be attributed to the provenance of the canvas, and citations in certain catalogues and special interest magazines. The variable " $\mathrm{c}(\mathrm{t})$ " reflects the timely effect of every year of sale and is necessary for designing an index of the contemporary Russian art market.

On the first stage of analysis, specific models were tested - the linear model, the semi-logarithmic model and the double logarithm model. In the first model, the price variable is used as the dependent variable. In the second model the logarithm of this variable is used. In the double logarithm model, not only the dependent variable, but 
also some continuous variables have logarithmic form. The explanatory power of the linear model was less than $50 \%$, and thus was excluded from further analysis. To define the most preferable functional form, the Pregibon link test was applied. According to these results, the double logarithm model was selected. Then, the F-test was applied to define the common significance of non-significant variables. Based on the results, the model equation was adjusted. The results of additional tests confirmed the statistical adequacy of the derived estimates.

Next, the price index of contemporary art was calculated by way of raising the exponent to the power of the coefficient with categorical variables of the year of sale. The movement of the index is shown in Fig. 3. As can be seen, the movement of the calculated index is in compliance with the movement shown in previous research. For example, R. Kraeussl, R. Logher [25] identified the sustainable growth of the index up to 2008. That examination conforms to the results we achieved. In general, the movement of the Russian contemporary art index conforms the movement of the index published on the analytical portal 'ArtPrice' for the world market of contemporary art [19]. Both markets showed an increase up to 2008 and a decline in the market after that year. In the years that followed 2008, the break was smoother, with a small growth in 2018. One can suppose that the same set of factors influence the Russian and the world markets of contemporary art.

Figure 3. Movements of the Russian contemporary art index

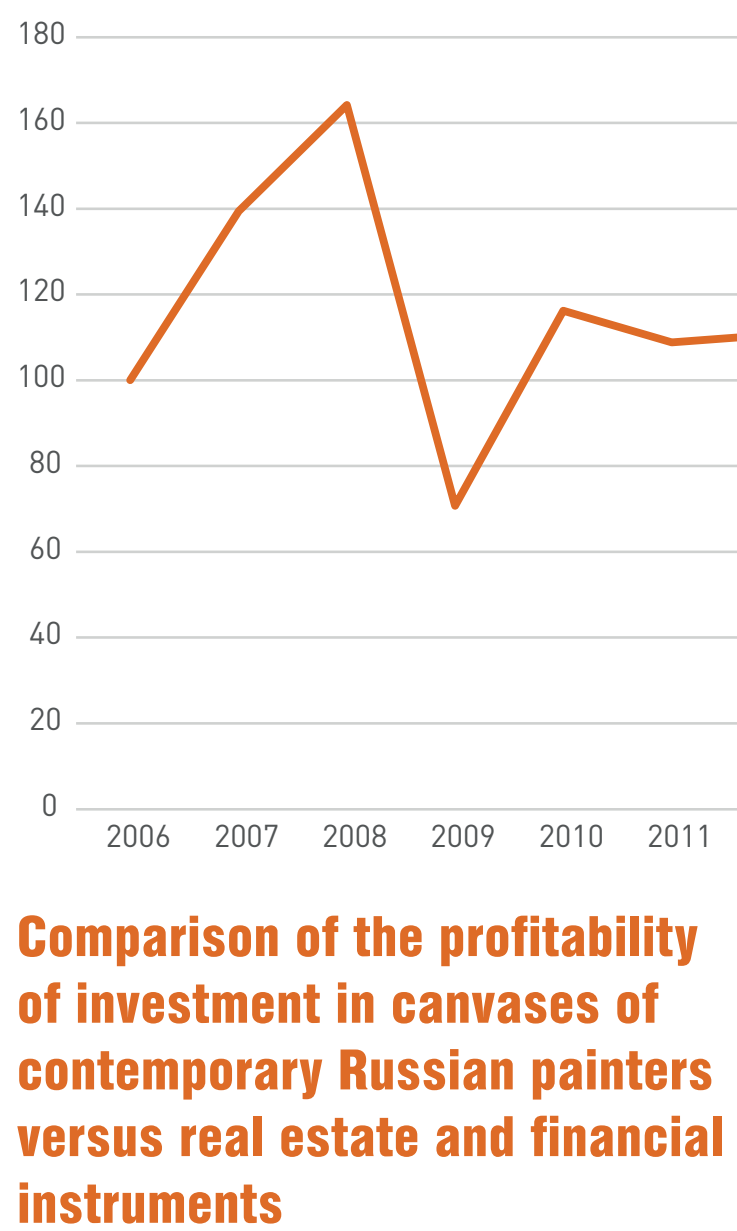

Most researchers develop a benchmarking analysis based around the profitability of the art market and financial instruments. However, as mentioned earlier, according the opinion of B. S. Frey and R. Eichenberger [2], the results of investment in the art market should be compared with the results of investment in real estate. The authors explain this by outlining the similarity of the characteristics (heterogeneity of the items and irregularity of transactions) and by their belonging to an alternative class of investment. In our study, a comparative analysis is presented which is based on traditional financial assets, and the indexes of the real estate market in Russia and the USA.
The comparison between Russian and American art markets is motivated by the following reasons. First of all, there is no data available for a separate and reliable index of European or Asian contemporary art markets (or an index of contemporary art market for one individual country). Secondly, the US art market is one of the most developed, largest and integrated art markets in the world. This implies that data is available for a lengthy time period. Finally, the goal of this research is to assess the performance of the Russian contemporary art market relative to the performance of other alternative and traditional investment asset classes, and only after that to check if the established relations hold in another country.

To estimate returns on real estate markets, we adopt the same approach as in the work of G. Candela, A. Scorcu [7]. We use a real estate market proxy for the Russian market based on the data of the Federal State Statistics Service [26]. This data includes the mean price of $1 \mathrm{~m}^{2}$ of the total area of typical apartments on the housing market (apartments of medium quality). The market proxy for high-end real estate in the Central Federal District was 
calculated separately. Just like art markets, real estate markets are characterised by significant transaction costs [27]. In Russia, they can reach as much as $25 \%$ of the property's sale price [28]. A broader range provided by Global Property Guide indicates that in Russia, transaction costs are approximately $22.71 \%-27.50 \%$ [29]. In our estimates, we incorporate mean transaction costs to avoid overestimation of returns on real estate market. Also, for the purposes of comparative analysis, the Case-Shiller index (an index of the real estate market in USA) and the S\&P 500 were used, and also the indexes of corporate bonds in the USA with a circulation period of 1-3 years and 10-15 years (ICE BofAML US Corp 1-3yr and ICE BofAML US Corp 10-15 yr), as well as treasury bonds with a circulation period of three months. Descriptive statistics for these investment instruments are shown in Table 2.

Table 2. Comparative characteristics of investment instruments in 2006-2019

\begin{tabular}{|c|c|c|c|c|c|c|c|c|c|}
\hline & $\begin{array}{l}\text { Contem- } \\
\text { porary Rus- } \\
\text { sian Art }\end{array}$ & $\begin{array}{l}\text { RTS } \\
\text { Index }\end{array}$ & $\begin{array}{l}\text { S\&P500 } \\
\text { Index }\end{array}$ & $\begin{array}{l}\text { US Cor- } \\
\text { porate } \\
\text { bonds } \\
1-3 y r\end{array}$ & $\begin{array}{l}\text { US } \\
\text { Corp } \\
\text { bonds } \\
10-15 y r\end{array}$ & $\begin{array}{l}\text { Case-Shill- } \\
\text { er home } \\
\text { price index }\end{array}$ & $\begin{array}{l}\text { US Gov } \\
\text { bonds } \\
\text { 3-month }\end{array}$ & $\begin{array}{l}\text { Russian Real } \\
\text { Estate Mar- } \\
\text { ket (Total) }\end{array}$ & $\begin{array}{l}\text { Russian } \\
\text { Real Estate } \\
\text { Market } \\
\text { (Luxury) }\end{array}$ \\
\hline $\begin{array}{l}\text { Average } \\
\text { return }\end{array}$ & $-3.08 \%$ & $3.03 \%$ & $6.91 \%$ & $3.2 \%$ & $6.37 \%$ & $1.43 \%$ & $1.16 \%$ & $8.52 \%$ & $15.06 \%$ \\
\hline Median & $-5.62 \%$ & $1.58 \%$ & $10.12 \%$ & $2.85 \%$ & $5.84 \%$ & $2.91 \%$ & $0.23 \%$ & $3.47 \%$ & $14.89 \%$ \\
\hline Maximum & $64.08 \%$ & $48.69 \%$ & $19.21 \%$ & $9.43 \%$ & $21.65 \%$ & $9.60 \%$ & $4.73 \%$ & $39.22 \%$ & $56.13 \%$ \\
\hline Minimum & $-56.85 \%$ & $-37.68 \%$ & $-21.95 \%$ & $0.87 \%$ & $-1.37 \%$ & $-9.45 \%$ & $0.03 \%$ & $-7.20 \%$ & $-40.02 \%$ \\
\hline $\begin{array}{l}\text { Standard } \\
\text { Deviation }\end{array}$ & $33.75 \%$ & $21.51 \%$ & $12.73 \%$ & $2.20 \%$ & $5.77 \%$ & $5.97 \%$ & $1.60 \%$ & $14.56 \%$ & $23.05 \%$ \\
\hline $\begin{array}{l}\text { Coefficient of } \\
\text { skewness }\end{array}$ & 0.17 & 0.27 & -1.27 & 1.71 & 1.26 & -0.57 & 1.35 & 1.23 & -0.52 \\
\hline $\begin{array}{l}\text { Coefficient of } \\
\text { kurtosis }\end{array}$ & 2.68 & 3.08 & 3.59 & 5.65 & 4.64 & 2.17 & 3.49 & 3.26 & 3.81 \\
\hline Sharpe ratio & -0.13 & 0.09 & 0.45 & 0.93 & 0.90 & 0.05 & - & 0.51 & 0.60 \\
\hline Treynor ratio & -0.042 & 0.031 & - & 1.050 & 0.302 & 0.008 & - & -0.382 & 0.463 \\
\hline
\end{tabular}

These results illustrate that investments in Russian contemporary art showed the lowest profitability among all the instruments analysed. The results in Table 2 for this class of assets do not correlate with the results of previous research, which focused on Russian art. For example, in the work of R. Kraeussl, R. Logher [25] a profitability figure of $12.57 \%$ of the Russian art market was indicated for the years 1986-2008. Nevertheless, it is worth noting that investments in contemporary art should not be directly compared with investments in art in general as they are more risky. This is because for most transactions there are no figures for repeated sales, e.g. due to special characteristics, or the possessor's realisation that it is more difficult to make an evaluation of the art object, etc. Our comparative analysis of the investments in contemporary Russian art with those in Russian real estate demonstrates that these two classes of assets cannot be accurately compared. Apart from this, the mean profitability of investment in art is less than the profitability of the RTS index and the profitability of high-end real estate, though investments in the canvases of contemporary Russian painters show an abnormal maximum profitability among all investment instruments analysed.

The calculation of the Sharpe ratio demonstrates that the best ratio of risk to profitability is associated with those investments in corporate bonds of US companies with different circulation periods, and in Russian high-end real estate. It is worth noting that investments in contemporary Russian art turned out to be the sole instrument with a negative Sharpe ratio. From a formal point of view, this indicates the necessity of excluding this instrument from investment portfolios. Meanwhile, very low values in the RTS index should be considered as a caution against investments in Russian shares.

\section{Evaluation of the CAPM model for diversification of investment portfolios by investment in contemporary Russian artwork}

According to the opinions of S. L. Glekov [4] and U. Gray [30] investments in art can be used to diversify investment portfolios. To check this hypothesis, we calculate the values of the CAPM model (Capital Asset Pricing Model). This calculation allows us to identify the metric value of market risk for every asset and the relation between the profitability of financial instruments and mid-market profitability. For the purpose of ascertaining the maximum suitability of this or that instrument in terms of diversifying investment portfolios, its coefficient should be below zero (i.e. having a negative correlation 
between the asset and the stock market). The CAPM model reflects a situation where the rate of return of short-term US Government loans (with a circulation period of 3 months) is used as the risk-free asset [31]. The American S\&P 500 index was chosen as the market portfolio. Calculation of the market risk premium and further regression analysis is shown in the results, as presented in Table 3 below.

To establish a situation where investments in art are an obviously beneficial instrument for diversification, a negative value for the coefficient is required. This value is inherent only to the Russian real estate market and federal loan bonds with a circulation period of 6 months. Therefore, the canvases of Russian contemporary painters should not be used for portfolio diversification. Using this coefficient, we can calculate the Treynor ratio, and with it we can make the conclusion about the reward-to-volatility ratio. The Treynor ratio for the asset " $\mathrm{i}$ " is calculated with the following formula:

Treynor Ratio $=\frac{\overline{R_{i}}-\overline{R_{f}}}{\beta_{i}}$

The results of the above calculation are shown in Table 2. The highest result associated with the Treynor ratio belongs to US Corporate bonds with a circulation period of 1-3 years. Much lower values for the Treynor ratio were calculated for the index of high-end real estate of the Central Federal District and the corporate bonds of US companies with a circulation period of 10-12 years. According to the results of the analysis, the Treynor ratio was negative for two instruments: the price index of contemporary Russian art and the index of Russian real estate. The profitability for the real estate index was higher than that for risk-free return, though the index was negative. This instrument is effective, because the risk is low (negative coefficient $\beta$ ), and the return of the instrument was higher than that of the risk-free rate. By contrast, the negative value of the Treynor ratio for the Russian contemporary art market indicates the inefficiency of investment, since the risk-free return is higher than the profitability of the asset with positive coefficient $\beta$.

Since not only foreign, but also Russian investors buy the canvases of Russian contemporary art, the CAPM model was applied to calculate values pertaining to Russian investors. The RTS index was chosen as the market portfolio and federal loan bonds (with a period of circulation of 6 months) was chosen as the risk-free asset. The results of this calculation are seen in Table 4.

Table 3. Results of the evaluation of model CAPM for the chosen investment instruments for 2006-2019

\begin{tabular}{|c|c|c|c|c|c|c|c|c|}
\hline & $\begin{array}{l}\text { Contem- } \\
\text { porary } \\
\text { Russian } \\
\text { Art }\end{array}$ & RTS Index & $\begin{array}{l}\text { Russian } \\
\text { Real Estate } \\
\text { Market } \\
\text { (Luxury) }\end{array}$ & $\begin{array}{l}\text { US Corp } \\
\text { bonds } 1-3 y r\end{array}$ & $\begin{array}{l}\text { US Corp } \\
\text { bonds } \\
10-15 y r\end{array}$ & $\begin{array}{l}\text { Case-Shill- } \\
\text { er home } \\
\text { price index }\end{array}$ & $\begin{array}{l}\text { Russian } \\
\text { Real Estate } \\
\text { Market } \\
\text { (Total) }\end{array}$ & OFZ 6 months \\
\hline Constant & -0.1005 & -0.0156 & 0.1218 & 0.0193 & 0.0422 & -0.0163 & 0.0847 & 0.2184 \\
\hline B & 1.0102 & 0.5972 & 0.3002 & 0.0194 & 0.1723 & 0.3292 & -0.1927 & -1.815 \\
\hline $\mathrm{R}^{2}$ & 0.1490 & 0.1403 & 0.029 & 0.0088 & 0.1111 & 0.4817 & 0.0346 & 0.3513 \\
\hline F-statistic & 2.10 & 1.96 & 0.36 & 0.11 & 1.50 & 11.15 & 0.43 & 6.50 \\
\hline $\begin{array}{l}\text { Constant } \\
\text { significance }\end{array}$ & $\begin{array}{l}\text { Not } \\
\text { significant }\end{array}$ & $\begin{array}{l}\text { Not } \\
\text { significant }\end{array}$ & $\begin{array}{l}\text { Not } \\
\text { significant }\end{array}$ & $\begin{array}{l}\text { Significant at } \\
5 \% \text { and } 10 \% \\
\text { level of signifi- } \\
\text { cance }\end{array}$ & $\begin{array}{l}\text { Significant } \\
\text { at } 5 \% \text { and } \\
10 \% \text { level } \\
\text { of signifi- } \\
\text { cance }\end{array}$ & $\begin{array}{l}\text { Not } \\
\text { significant }\end{array}$ & $\begin{array}{l}\text { Significant } \\
\text { at } 10 \% \text { level } \\
\text { of signifi- } \\
\text { cance }\end{array}$ & $\begin{array}{l}\text { Significant at } \\
5 \% \text { and } 10 \% \\
\text { level of signifi- } \\
\text { cance }\end{array}$ \\
\hline
\end{tabular}

Table 4. Results of the estimation of the CAPM model for Russian investors

\begin{tabular}{llllll} 
& Constant & B & $\mathbf{R}^{2}$ & F-statistic & Constant significance \\
\hline Contemporary Russian art & -0.0594 & 1.0177 & 0.7616 & 38.33 & Not significant
\end{tabular}

According to the results of these calculations, the index is significant to any reasonable level of significance. The values of this index can be compared with the values in Table 3. The presented index is positive, and therefore the canvases of contemporary Russian painters should not be recommended for diversification of the portfolios of Russian investors.

Finally, we can calculate the correlation ratio for the above-mentioned investment instruments (Table 5).
The price index of contemporary Russian art has a positive correlation with all considered instruments of the stock market (excluding federal loan bonds) and the index of Russian real estate. These type of investments have a negative correlation with the Case-Shiller index and the index of Russian high end real estate. So, the investments in Russian contemporary art should not be widely used for the risk diversification of investment portfolios. 
Table 5. Correla tion of investment instrument for the period 2006-2019

\begin{tabular}{|c|c|c|c|c|c|c|c|c|c|c|}
\hline & $\begin{array}{l}\text { Contemporary } \\
\text { Russian Art }\end{array}$ & RTS Index & S\&P500 Index & $\begin{array}{l}\text { US Corporate } \\
\text { bonds 1-3yr }\end{array}$ & $\begin{array}{l}\text { US Corp bonds } \\
\text { 10-15yr }\end{array}$ & $\begin{array}{l}\text { Case-Shiller home } \\
\text { price index }\end{array}$ & $\begin{array}{l}\text { Russian Real Estate } \\
\text { Market (Luxury) }\end{array}$ & $\begin{array}{l}\text { Russian Real Estate } \\
\text { Market (Total) }\end{array}$ & $\begin{array}{l}\text { US Gov bonds } \\
\text { 3-month }\end{array}$ & OFZ 6 months \\
\hline $\begin{array}{l}\text { Contemporary Rus- } \\
\text { sian Art }\end{array}$ & 1 & & & & & & & & & \\
\hline RTS Index & 0.5075 & 1 & & & & & & & & \\
\hline S\&P500 Index & 0.4005 & 0.4374 & 1 & & & & & & & \\
\hline $\begin{array}{l}\text { US Corporate bonds } \\
1-3 y r\end{array}$ & 0.4958 & 0.2674 & 0.0366 & 1 & & & & & & \\
\hline $\begin{array}{l}\text { US Corp bonds 10- } \\
15 \mathrm{yr}\end{array}$ & 0.3200 & -0.0275 & 0.2987 & 0.7355 & 1 & & & & & \\
\hline $\begin{array}{l}\text { Case-Shiller home } \\
\text { price index }\end{array}$ & -0.0383 & 0.1882 & 0.6889 & -0.5139 & -0.2336 & 1 & & & & \\
\hline $\begin{array}{l}\text { Russian Real Estate } \\
\text { Market (Luxury) }\end{array}$ & -0.0145 & 0.1566 & 0.1983 & -0.1773 & -0.3010 & 0.6049 & 1 & & & \\
\hline $\begin{array}{l}\text { Russian Real Estate } \\
\text { Market (Total) }\end{array}$ & 0.2908 & 0.5997 & -0.0790 & 0.1612 & -0.2975 & -0.0199 & 0.4993 & 1 & & \\
\hline $\begin{array}{l}\text { US Gov bonds } \\
\text { 3-month }\end{array}$ & 0.1588 & 0.6991 & -0.0114 & 0.0469 & -0.4338 & -0.0650 & 0.3040 & 0.8291 & 1 & \\
\hline OFZ 6 months & -0.3564 & -0.3914 & -0.5979 & -0.3509 & -0.4849 & -0.3330 & 0.0820 & 0.2123 & 0.0252 & 1 \\
\hline
\end{tabular}




\section{Conclusion}

According to the estimates for the period studied herein, including the crisis of 2008 and the period subsequent to the anti-Russian sanctions of 2014, we have to draw the conclusion that the canvases of contemporary Russian painters present relatively unattractive investment opportunities in terms of profitability or stability from the perspective of portfolio diversification.

\section{Bibliography}

1. Faye, B. An endogenous Representation of the contemporary art market cycle. Speculation and decoupling of artistic and market classification of living artists. Bankers, Markets \& Investors. 2009;100: 37-49.

2. Frey, B., Eichenberger, R. On the Return of Art Investment Return Analyses. Journal of Cultural Economics. 1995; 19(3): 207-220.

3. Baumol W. J. Unnatural value: or art investment as floating crap game. The American Economic Review. 1986; 76(2): 10-14.

4. Glekov S.L. Investicionnyj potencial art-rynka. Izv. vyssh. ucheb. zavedenij. Ser.: Ekonomika, finansy i upr. proizvodstvom. 2012; 3: 46-51. (In Russ.).

5. Chanel, O., Gerard-Varet, L., Ginsburgh, V. Prices and Returns on Paintings: An Exercise on How to Price the Priceless. The Geneva Papers on Risk and Insurance Theory. 1994; 19(1): 7-21.

6. Court, L. Entrepreneurial and Consumer Demand Theories for Commodity Spectra: Part I. Econometrica. 1941; 9(2): 135-162; 241-297.

7. Candela, G., Scorcu, A. A Price Index for Art Market Auctions: An Application to the Italian Market of Modern and Contemporary Oil Paintings. Journal of Cultural Economics. 1997; 21(3): 175-196.

8. Nahm, J. Price determinants and genre effects in the Korean art market: A partial linear analysis of size effect. Journal of Cultural Economics. 2010; 34(4): 281-297.

9. Higgs, H., Forster, J. The auction market for artworks and their physical dimensions: Australia-1986 to 2009. Journal of Cultural Economics. 2014; 38(1): 85-104.

10. Campbell, R. A. J. Art as a Financial Investment. Journal of Alternative Investments. 2008; 10(4): 64-81.

11. Urbi, G., Gwendoline, V., Villalobos, E. Art as an investment alternative: The case of Argentina. Academia. 2017; 30(3): 362-382.

12. Ashenfelter, O., Graddy, K. Auctions and the price of art. Journal of Economic Literature. 2003; 41: 763-786.
13. Codignola, F. The Art Market, Global Economy and Information Transparency. Symphonya - Emerging Issues in Management. 2003; 2: 73-93.

14. Suharev A.N. Art-rynok: dinamika i sovremennoe sostoyanie. Finansy i kredit. 2013; 45: 19-24. (In Russ.).

15. Mihlin A.V. Art--indeksy: korrelyaciya cen na predmety iskusstva s cenami drugih aktivovi nekotorye effekty art-rynka. Imushchestvennye otnosheniya v Rossijskoj Federacii. 2014; 4: 83-90. (In Russ.).

16. Shchurina S.V. Investicii v ob"ekty iskusstva finansovyh institutov i bankov. Finansy i kredit. 2015; 24: 54-66. (In Russ.).

17. Informaciya ob internet-proekte ARTinvestment. RU. URL: https://artinvestment.ru/about/about_us/ (accessed on 27.03.2019). (In Russ.).

18. Rynok russkogo iskusstva - 2018. Itogi. URL: https://artinvestment.ru/russian-art-marketreports/2018.html (accessed on 27.03.2019). (In Russ.).

19. The Contemporary Art Market report 2018. URL: https://www.artprice.com/artprice-reports/thecontemporary-art-market-report-2018/generalsynopsis-contemporary-arts-market-performance (accessed on 27.03.2019).

20. Shilova A. InArt predstavlyaet: top-10 rabot rossijskih sovremennyh hudozhnikov po aukcionnoj stoimosti. URL: https://in-art.ru/news/analiticheskiespravki/inart-predstavlyaet-top-10-rabot-rossiyskikhsovremennykh-khudozhnikov-po-auktsionnoystoimosti/ (accessed on 27.03.2019). (In Russ.).

21. Shilova A. Rynok rossijskogo sovremennogo iskusstva rastet! InArt ocenil ob"em prodazh v 2018 godu. URL: https://in-art.ru/news/analiticheskiespravki/rynok-rossiyskogo-sovremennogo-iskusstvarastet-inart-otsenil-obem-prodazh-v-2018-godu/ (accessed on 27.03.2019). (In Russ.).

22. McAndrew. C. The Art Market 2018. An Art Basel \& UBS Report. URL: https://d2u3kfwd92fzu7. cloudfront.net/Art\%20Basel\%20and\%20UBS_ The\%20Art\%20Market_2018.pdf (accessed on 27.03.2019).

23. Top 100 priznannyh avtorov. URL: https://in-art.ru/ ratings/recognized-top/ (accessed on 27.03.2019). (In Russ.).

24. Kulakov, N., Blaset Kastro, A. Evaluation of Financial Instruments Possessing Non-Conventional Cash Flow. Journal of Corporate Finance Research. 2018; 12(2): 7-17.

25. Kraeussl R., Logher R. Emerging art markets. Emerging Markets Review. 2010; 11: 301-318. 
26. Russian Federal State Statistics Service. URL: http:// www.gks.ru/dbscripts/cbsd/DBInet.cgi (accessed on 27.03.2019). (In Russ.).

27. Chibikova T.V., Krumina K.V. Harakternye osobennosti rynka nedvizhimosti v sravnenii s ego vysokoorganizovannoj formoj. Vestnik Sibirskoj gosudarstvennoj avtomobil'no-dorozhnoj akademii. 2017; 3(55): 189-196. (In Russ.).

28. Maksimov S. N., Vasil'eva N. V., Bachurinskaja I. A. Problemy ocenki i snizhenija transakcionnyh izderzhek na rynke nedvizhimosti. Problemy sovremennoj jekonomiki. 2013; 1(45): 160-162. (In Russ.).

29. Buying costs in Russia are among the highest in Europe. URL: https://www.globalpropertyguide. com/Europe/Russia/Buying-Guide (accessed on 26.06.2020).

30. Garay, U., Vielma, G., Villalobos, E. Art as an investment alternative: the case of Argentina. Academia Revista Latinoamericana de Administración. 2017; 30(3): 362-382.

31. Jensen M. C. The performance of mutual funds in the period 1945-1964. The Journal of finance. 1986; 23(2): 389-416. 